\title{
PENERAPAN SYARI'AH DALAM SISTEM PEMERINTAHAN NATION-STATE PERSPEKTIF HISTORIS DAN FIQH SIYASAH
}

\author{
Rupi'i Amri \\ Fakultas Syari'ah dan Hukum UIN Walisongo Semarang \\ Jl. Prof. Dr. Hamka Kampus III Ngaliyan Semarang 50185 \\ Telp. (024) 7601291, HP. 085842800117 \\ E-Mail: rupiiamri@gmail.com, rupii@walisongo.ac.id
}

\begin{abstract}
The tendency to apply sharia to the state or government by some Muslims is a very interesting new phenomenon in many Muslim countries. Several Muslim countries, such as Indonesia, Pakistan, Jordan, Sudan, Egypt, Morocco, Kuwait and Iran are examples of countries where "Islamist" groups want to implement sharia into government. Of course this desire raises different views from Islamic figures, some support and some oppose it. This paper seeks to find answers to the problems that arise from the views of supporters and opponents of the Islamic state, with the core of the problem are: (1) seeking and knowing the concept of Islam and Caliphate in the Islamic political system; (2) explaining the government system according to historical perspective; namely in the era of the Prophet Muhammad and Khulafa ar-Rasyidin; and (3) explaining the relationship between religion and state in the concept of siyasa figh. The conceptual framework used in this paper is that there are two important things to be achieved in politics, namely (1) politics as anything related to state administration; and (2) politics as all activities directed to seek and maintain power in society. In relation to this, there is often a "tension" between groups that want to implement the Shari'ah into the rules of government with groups that oppose it. If the desires of the two groups cannot be met, then there is no possibility of various acts of violence in a country, and can even lead to a coup against the current government. Some findings from this study are that (1) System of government in an Islamic perspective is not clearly stated in the Quran and Sunnah so that Islamic political thinkers disagree over what government system must be applied in a nation state; (2) In a historical perspective, the system of government in the time of the Prophet Muhammad was more concerned with the substance of Islamic values into the system of state government. This can be seen rules of the Madina Constitution, while the government of the Khulafa ar-Rasyidin used a system of power of autocracy and monarchic dynasty; (3) Islamic political thinkers differ in their views on the relation between religion and state in the concept of siyasa figh into three groups, namely (1) religion and state must be integrated and cannot be separated because the state is a political and religious institution; (2) religion and state are not related at all because the Prophet Muhammad was only an ordinary prophet like the previous prophet with the single task of inviting people back to noble life; (3) religions and state relate reciprocally and need each other.
\end{abstract}

Keywords: implementation, sharia, religion, nation-state.

Abstrak: Kecenderungan untukmenerapkan syariah Islam ke dalam negara atau pemerintahan oleh sebagian orang Islam merupakan gejala baru yang sangat menarik di banyak negara Muslim. Beberapa negara muslim, seperti Indonesia, Pakistan, Yordania, Sudan, Mesir, Maroko, Kuwait dan Iran merupakan contoh negara-negara di mana kelompok-kelompok "Islamis"-nya ingin menerapkan syariah ke dalam pemerintahan. Tentu saja keinginan tersebut menimbulkan pandangan yang berbeda-beda dari tokoh-tokoh Islam, sebagian ada yang mendukung dan sebagian lagi menentangnya. Tulisan ini berusaha untuk mencari jawaban terhadap permasalahan-permasalahan yang muncul dari pandangan para pendukung 
dan penentang negara syariah, dengan inti permasalahannya adalah : (1) mencari dan mengetahui konsep Islam dan Kekhalifahan dalam sistem politik Islam; (2) menjelaskan sistem pemerintahan dalam perspektif historis, terutama pada masa Nabi Muhammad dan Khulafa ar-Rasyidin, dan (3) menjelaskan hubungan agama dan negara dalam konsep figh siyasah. Kerangka konseptual yang dipergunakan dalam tulisan ini adalah bahwa terdapat dua hal penting yang hendak dicapai dalam politik, yaitu (1) politik sebagai segala yang berkaitan dengan penyelenggaraan negara; dan (2) politik sebagai segala kegiatan yang diarahkan untuk mencari dan mempertahankan kekuasaan dalam masyarakat. Dalam kaitannya dengan hal tersebut, seringkali terjadi "ketegangan" antara kelompok yang ingin menerapkan syari'ah ke dalam aturan-aturan pemerintahan dengan kelompok yang menentangnya. Apabila keinginan darikedua kelompoktersebut tidak dapat dipertemukan, maka tidakmenutup kemungkinanakan terjadi berbagai tindak kekerasan dalam suatu negara, dan bahkan dapat menimbulkan kudeta terhadap pemerintahan yang sedang berjalan. Beberapa temuan dari peneletian ini adalah (1) Sistem pemerintahan dalam perspektif Islam tidak disebutkan secara jelas dalam al-Quran dan Sunnah sehingga para pemikir politik Islam berbeda pendapat tentang sistem pemerintahan apa yang harus diterapkan ke dalam sebuah negara-bangsa (nation-state); (2) Dalam perspektif historis, sistem pemerintahan pada masa Nabi Muhammad lebih mementingkan substansi nilai-nilai Islam ke dalam sistem pemerintahan negara. Hal ini dapat dilihat pada aturan-aturan yang tertuang dalam Piagam Madinah, sedangkan pemerintahan pada masa Khulafa" ar-Rasyidin menggunakan sistem "autocratic power" (kekuatan autokrasi) dan a dynastic monarchy" (dinasti monarkhi); (3) Para pemikir politik Islam berbeda pandangan dalam menyikapi relasi agama dan negara dalam konsep figh siyasah menjadi tiga kelompok, yaitu pertama, agama dan negara harus terintegrasi dan tidak dapat dipisahkan sebab negara merupakan lembaga politik dan sekaligus keagamaan, kedua, antara agama dan negara tidak berhubungan sama sekali (terpisah) karena Nabi Muhammad hanyalah seorang Rasul biasa seperti halnya rasul-rasul sebelumnya, dengan tugas tunggal mengajak manusia kembali kepada kehidupan yang mulia, ketiga, agama dan negara berhubungan secara timbal balik dan saling membutuhkan.

Kata kunci: penerapan, syariah, agama, negara-bangsa.

\section{PENDAHULUAN}

Keinginan untuk menerapkan syari'ah Islam ke dalam konstitusi negara merupakan kecenderungan baru yang sangat menarik di beberapa negara Muslim belakangan ini. Keinginan ini didasari pada banyaknya permasalahan bangsa yang tidak dapat diatasi dengan segera melalui landasan konstitusi yang sudah ada. Beberapa negara muslim, seperti Indonesia, dengan aksi-aksi yang dilakukan oleh aktifis Front Pembela Islam (FPI), Majelis Mujahidin Indonesia (MMI), dan sebagian memasukkan Partai Keadilan Sejahtera (PKS), merupakan contoh gerakan dari kelompok dan partai Islam yang memperjuangkan syariah Islam ke dalam sistem pemerintahan. Negaranegara Muslim lain, seperti Al-Jazair dengan FIS-nya, Pakistan, Yordania, Sudan,
Mesir, Maroko, dan Kuwait merupakan contoh negara-negara di mana kelompokkelompok "Islamis"-nya senantiasa ikut bersaing di pentas politik nasional masing-masing dengan menggunakan prosedur pemilihan umum. ${ }^{1}$ Meskipun demikian, sebagian besar pemerintahan Islam dibangun lewat prosedur nondemokrasi. Arab Saudi misalnya, secara konsisten memberlakukan syariah Islam dalam kehidupan sosial-politik melalui jalur otoritarianisme sejak Muhammad asSaud dan Muhammad b. 'Abd al-Wahhab menyepakati suatu kontrak politik yang melahirkan kerajaan kaya minyak itu.

1 Burhanuddin, "Pengantar Editor" dalam buku Syariah Islam Pandangan Muslim Liberal, (Jakarta: The Asia Foundation dan Jaringan Islam Liberal, 2003), hlm. viii. 
Pemerintahan Taliban sebelum dirobohkan koalisi Amerika Serikat juga menjadi contoh yang baik betapa otoritarianisme menjadi jalan tol bagi pelaksanaan syariah Islam yang eksesif di Afganistan. Demikian juga di Pakistan pada tahun 1980-an di mana program "Islamisasi" yang digelindingkan oleh rezim militer di bawah Zia ul-Haq menarik minat kekuatan politik Islamis - yang tidak pernah menuai simpati rakyat dalam pemilu seperti Jamaati-Islami yang didirikan Abu A'la al-Maududi - untuk berkolaborasi dengan militer. ${ }^{22}$

Di sisi lain, Iran merupakan negara yang "berhasil" menerapkan syariah Islam ke dalam konstitusi negara. Pada tanggal 1 April 1979, Ayatullah Khomeini menjadikan Iran sebagai Negara Republik Islam yang dipimpin oleh seorang fuqaha dan sejak saat itu berakhirlah dinasti monarkhi Syah Pahlevi. ${ }^{33}$ Iran, di bawah Khomeini berusaha menerapkan syariah Islam dan mempersatukan umat di bawah seorang pemimpin, kemudian menerapkan pemerintahan yang adil di bawah kedaulatan Tuhan (Sovereignity of God). Dengan teori wilayah al-faqih-nya, Khomeini memandang perlunya pemerintahan Islam di zaman gaibnya Imam. Ia melihat imam merupakan pemegang kekuasaan eksekutif, yang fungsinya adalah menerapkan hukum-hukum Ilahiyah dan bukan hanya menjelaskannya seperti yang banyak dipahami oleh kalangan tradisional. Khomeini menilai bahwa semua tanggung jawab dan kekuasaan lain Nabi berpindah ke tangan ulama, dengan pengecualian hak istimewa menerima wahyu Ilahiyah. ${ }^{44}$

Senada dengan Khomeini, pandangan mengenai perlunya penerapan syariah Islam ke dalam konstitusi negara juga dikemukakan oleh Muhammad Asad.

2 Burhanuddin, Pengantar ..., hlm. viii.

3 Lihat David E. Long, "Islamic Republic of Iran" dalam The Government and Politics of the Middle East and North Africa, (Washington : Westview Press, 1986), hlm. 60.

4 Imam Khomeini, Al-Hukumah al-Islamiyyah, (Teheran : Maktabah al-Islamiyyah al-Kubra, t.t.), hlm. 48-49.
Menurut Asad, sebuah negara akan dapat menjadi "negara Islam" jika ajaran Islam tentang sosio-politik dilaksanakan dalam kehidupan rakyat berdasarkan konstitusi. ${ }^{55}$ Asad menolak sistem negara sekuler karena dalam suatu negara sekuler modern, tidak ada norma tetap yang dapat dipakai untuk menimbang antara yang baik dan buruk, dan antara yang benar dan salah. Satu-satunya kriteria adalah "kepentingan bangsa" (nation's interest). ${ }^{66}$ Namun demikian, meskipun Asad setuju terhadap penerapan syariah Islam ke dalam konstitusi negara, tetapi bentuk negara Islam yang sesuai dengan hukum syari'ah, menurut Asad tidak hanya satu, melainkan banyak yang secara eksplisit dan tegas kaitannya dengan kehidupan komunal. ${ }^{77}$

Di sisi lain, terdapat kelompok yang menolak penerapan syariah Islam ke dalam konstitusi negara. Tokohnya antara lain adalah Abdullah Ahmed anNaim. Beberapa alasan yang dikemukakan oleh an-Naim adalah pertama, sulitnya berbicara tentang pemerintahan Nabi dalam perspektif konstitusionalisme. Konstitusionalisme mengimplikasikan pembatasan hukum atas kekuasaan penguasa dan pertanggungjawaban politiknya terhadap sekelompok manusia lain, sedangkan Nabi, bagi kaum Muslim adalah utusan Allah, di mana setiap kata dan perbuatannya merupakan satusatunya kriteria validitas dan legalitas. ${ }^{88}$ Kedua, problem yang berkenaan dengan syura sebagai prinsip konstitusional adalah karena konsep dan otoritasnya yang asli dalam al-Qur'an, juga prakteknya dalam sejarah, tidak memiliki ruang lingkup yang komprehensifmaupun efek yang mengikat. ${ }^{99}$

5 Muhammad Asad, The Principles of State and Government in Islam, (Kuala Lumpur : Islamic Book Trust, 2001), hlm. 1.

6 Muhammad Asad, The Principles ..., hlm. 5.

7 Muhammad Asad, The Principles ..., hlm 22-29.

8 Abdullah Ahmed an-Naim, Toward an Islamic Reformation (Civil Liberties, Human Rights and International Law), (New York: Syracuse University Press, 1990), hlm. 76-77.

9 Abdullah Ahmed an-Naim, Toward ..., hlm. 7879 . 
Ketiga, problem tentang kedaulatan. Penilaian konstitusional atas model syariah menunjukkan perlunya klarifikasi dua konsep yang sangat berhubungan dengan konstitusionalisme modern, yakni kedaulatan dan kewarganegaraan. Menurut an-Naim, semua problem konstitusionalisme dalam syariah adalah ambivalensi tertentu dalam hal kedaulatan. Dalam negara syariah, kedaulatan tertinggi terletak di tangan Allah, tetapi tidak dengan sendirinya menunjuk siapa yang berwenang untuk bertindak atas nama kedaulatan tertinggi itu. ${ }^{1010}$

Tulisan ini akan membahas tentang sistem pemerintahan dari sudut pandang historis dan fiqh siyasah (figh politik), terutama pemerintahan Islam yang pernah dialami oleh umat Islam dalam dinamika sejarah pemerintahan Islam, sejak masa Nabi Muhammad Saw., Khulafa' ar-Rasyidin dan masa-masa sesudahnya.

\section{METODE PENELITIAN}

Jenis penelitian ini adalah library research, dengan menggali data-data berupa dokumen tertulis, baik dalam buku-buku karya ilmiah atau tulisan yang berkaitan dengan pemikiran ulama tentang sistem pemerintahan. Pendekatannya menggunakan pendekatan filosofis, yaitu pendekatan untuk meneliti pemikiran tokoh atau ulama dan mengungkapkan makna di balik hakekat segala sesuatu yang nampak dari berbagai teks tulisan dan catatan naskah-naskah yang telah diterbitkan.

Paradigma yang digunakan dalam penelitian ini adalah berdasarkan penelitian kualitatif. ${ }^{1111} \mathrm{Hal}$ ini dikarenakan penelitian ini berupa teks tertulis. Penelitian kualitatif dalam penulisan ini mentikberatkan pada

10 Abdullah Ahmed an-Naim, Toward ..., hlm. 8283.

11 Penelitian kualitatif adalah penelitian yang menitikberatkan pada proses dengan metode analisis deduktif, induktif, komparatif, interpretatif, analisis isi, hermeneutic dan verstehen. Lihat Sudarno Shobron dkk, Pedoman Penulisan Tesis (Surakarta: Sekolah Pascasarjana UMS, 2014), hlm. 11. proses dengan metode analisis deskriptif dan interpretatif. Oleh karena itu, penelitian kualitatif merupakan prosedur yang menghasilkan data deskriptif berupa teks tertulis dari orang yang berperilaku atau pemikiran yang dapat diamati. Pendekatan ini juga diarahkan pada latar belakang dan individu para tokoh atau ulama secara utuh (holistik). Orang dan perilaku ini bisa juga berupa teks yang tertulis. Adapun langkahlangkah yang digunakan adalah sebagai berikut: 1) Paradigma penelitian, 2) Jenis penelitian, 3) Pendekatan, 4) Sumber Data, 5) Pengumpulan Data, 6) Validitas Data, dan 7) Analisis Data.

Sumber datanya terdiri atas dua bagian yaitu sumber data primer dan sekunder. Pertama, sumber data primer akan menelaah pemikiran ulama atau ahli fiqh siyasah, baik berupa buku-buku maupun artikel-artikel. Kedua, sumber sekunder, yaitu data-data yang bersumber pada bukubuku, tulisan-tulisan, atau karangan orang lain yang dapat diperoleh dari buku, jurnal, majalah, hasil-hasil penelitian (tesis dan disertasi), dan sumber-sumber lain yang sesuai (koran, internet, dan lain-lain), yang berkaitan dengan penelitian tersebut.

Tehnik analisis datanya menggunakan Content Analysis, sebagaimana dikemukakan Suryabrata ${ }^{1212}$ bahwa Content Analysis adalah menganalisis data sesuai dengan kandungan isinya. Dengan ini data-data yang dikumpulkan adalah bersifat deskriptif dan data tekstual yang bersifat fenomenal, maka dalam mengelola data-data tersebut penulis menggunakan analisis isi. Dengan analisis ini penulis melakukan analisis data secara ilmiah dan menyeluruh tentang sistem pemerintahan dalam perspektif fiqh siyasah.

\section{HASIL DAN PEMBAHASAN Islam dan Kekhalifahan}

Islam, dilihat dari perspektif teologis merupakan sistem nilai dan ajaran yang bersifat Ilahiyah dan karena itu sekaligus

12 Sumadi Suryabrata, Metode Penelitian, (Jakarta: Rajawali Press, 1998), hlm. 94, 
bersifat transenden, sedangkan dari sudut sosiologis, Islam merupakan fenomena peradaban, kultural dan realitas sosial dalam kehidupan manusia. Islam dalam realitas sosial tidak sekedar sejumlah doktrin yang bersifat menzaman dan menjagat raya (universal), tetapi juga mengejawantahkan diri dalam institusi-institusi sosial yang dipengaruhi oleh situasi dan dinamika ruang dan waktu. ${ }^{1313}$

Dalam al-Qur'an terdapat sejumlah ayat yang mengandung petunjuk dan pedoman bagi manusia dalam hidup bermasyarakat dan bernegara. Di antara ayat-ayat tersebut terdapat beberapa ayat yang mengajarkan tentang kedudukan manusia di Bumi dan prinsip-prinsip yang harus diperhatikan dalam kehidupan kemasyarakatan, seperti prinsip-prinsip musyawarah atau konsultasi, ketaatan kepada pemimpin, keadilan, persamaan dan kebebasan beragama. ${ }^{1414}$ Beberapa ayat yang dijadikan dasar dan pedoman bagi manusia dalam kehidupan bermasyarakat dan bernegara adalah sebagai berikut : 1) Kedudukan Manusia di Bumi (Q.s. Ali Imran: 26, Q.s. Al Hadid: 5, Q.s. Al An'am: 165, Q.s. Yunus: 14), 2) Musyawarah atau Konsultasi (Q.s. Ali Imran: 159, Q.s. As-Syura:38), 3) Ketaatan kepada Pemimpin (Q.s. An Nisa': 59), 4) Keadilan (Q.s. An Nahl: 90, Q.s. An Nisa': 58), 5) Persamaan (Q.s. Al-Hujurat: 13), 6) Hubungan antar Umat dari Berbagai Agama (Q.s. Al-Baqarah: 256, Q.s. Yunus: 55, Q.s. Ali Imran: 64, Q.s. Al-Mumtahanah: 8-9)..$^{1515}$

Di samping ayat-ayat tersebut di atas, masih terdapat beberapa ayat yang menjelaskan tentang "kekuasaan politik" serta tugas yang dibebankan oleh Allah kepada manusia. Istilah yang digunakan

13 Dalam perjalanan sejarahnya, Islam sebagai agama dan sistem nilai yang bersifat transenden, menuntut para penganutnya untuk memahami "realitas", yang pada gilirannya mewujudkan pola-pola pandangan dunia (weltanschauung) tertentu. Lihat Azyumardi Azra, Pergolakan Politik Islam, (Jakarta : Paramadina, 1996), hlm. i-iii.

14 Munawir Sjadzali, Islam dan Tata Negara, (Jakarta : UI Press, Edisi Kelima, 1993), hlm. 4.

15 Munawir Sjadzali, Islam ..., hlm. 4-7.
al-Qur'an adalah istikhlaf (Q.s. Al-Baqarah: 30, Q.s. Shad: 26), dan isti'mar (Q.s. Hud: 6, Q.s. At-Taubah: 17-18, Q.s. Ar Rum: 9). ${ }^{1616 .}$ Ayat-ayat yang berbicara tentang pengangkatan khalifah dalam al-Qur'an ditujukan kepada Nabi Adam As. dan Nabi Daud. As. Khalifah pertama adalah manusia pertama (Adam) dan ketika itu belum ada masyarakat manusia, berbeda dengan keadaan pada masa Nabi Daud. Ia berhasil menjadi khalifah setelah membunuh Jalut. ${ }^{1717}$ Dalam ayat tersebut dapat dipahami bahwa Daud memperoleh kekuasaan tertentu dalam mengelola satu wilayah, dan dengan demikian kata khalifah pada ayat yang membicarakan pengangkatan Daud adalah kekhalifahan dalam arti kekuasaan mengelola wilayah atau dengan kata lain kekuasaan politik. ${ }^{1818}$

Kekhalifahan dalam arti kekuasaan politik dipahami juga dari ayat-ayat yang menggunakan bentuk jamak khulafa', seperti dalam Q.s. Al-A'raf/7: 69 dan 74, serta Q.s. An-Naml/27: 62. Ayat yang menjelaskan bahwa Allah akan mengangkat khalifah di muka Bumi (Q.s. Al-Baqarah/2: 30) menginformasikan juga unsur-unsur kekhalifahan sekaligus kewajiban sang khalifah. Unsur-unsur tersebut adalah (1) Bumi atau wilayah; (2) Khalifah yang diberi kekuasaan politik atau mandataris, serta (3) hubungan antara pemilik kekuasaan dengan pemberi kekuasaan (Allah Swt). ${ }^{1919}$

Dalam surat Hud/11: 6 Allah berfirman : "Dia (Allah) yang menciptakan kamu dari Bumi dan menugaskan kamu memakmurkannya." Kata "amara dapat diartikan dengan dua makna sesuai dengan obyek dan konteks uraian ayat. Dalam Surat At-Taubah/9: 17 dan 18 yang menggunakan kata ya'muru dan ya'muru dalam konteks uraian tentang masjid diartikan memakmurkan masjid dengan jalan membangun, memelihara,

16 M. Quraish Shihab, Wawasan Al-Qur'an (Tafsir Maudhu'i atas Pelbagai Persoalan Umat), (Bandung : Mizan, Cetakan XI, 2000), hlm. 422.

17 Lihat Q.s. Al-Baqarah/2: 251.

18 M. Quraish Shihab, Membumikan Al-Qur'an, (Bandung: Mizan, 1992), hlm. 423.

19 M. Quraish Shihab, Membumikan ..., hlm. 424. 
memugar, membersihkan, shalat atau i'tikaf (berdiam diri) di dalamnya. Sementara itu dalam Surat Ar-Rum/30: 9 yang mengulangi kata kerja masa lampau 'amaru berbicara tentang Bumi, diartikan sebagai membangun bangunan serta mengelolanya untuk memperoleh manfaatnya.

Jika demikian kata ista'marakum dapat berarti "menjadikan kamu" atau "meminta/menugaskan kamu" mengolah Bumi guna memperoleh manfaatnya. Dari satu sisi penugasan tersebut dapat merupakan pelimpahan kekuasaan politik, di sisi lain karena yang menjadikan dan yang menugaskan itu adalah Allah Swt., maka para petugas dalam menjalankan tugasnya harus memperhatikan kehendak yang menugaskannya. ${ }^{2020}$ Ayat lain yang penting untuk dicermati adalah ayat yang menerangkan tentang perintah taat kepada penguasa (ulil amri) yang didahului dengan perintah untuk menunaikan amanat (Q.s. AnNisa'/4: 58-59). Kedua ayat tersebut dinilai oleh para ulama sebagai prinsip-prinsip pokok yang menghimpun ajaran Islam tentang kekuasaan atau pemerintahan. Moh. Rasyid Ridha berpendapat bahwa "Seandainya tidak ada ayat lain yang berbicara tentang hal pemerintahan, maka ayat ini telah amat memadai." 2121

Di samping itu dalam Surat AnNisa'/4: 58-59 tersebut menurut Al-Maraghi, sebagaimana dikutip oleh Quraish Shihab, menjelaskan prinsip-prinsip ajaran agama dalam bidang pemerintahan serta sumbersumbernya, yaitu :

1. Al-Qur'an al-Karim yang ditunjuk oleh perintah agar taat kepada Allah.

2. Sunnah Rasul Saw. yang ditunjuk oleh kewajiban taat kepada Rasul.

3. Konsensus ulul amr, yakni mereka yang diberi kepercayaan oleh umat, seperti para ulama, cerdik cendekia, pemimpin militer, penguasa, petani, industriawan, buruh, wartawan, dan

20 M. Quraish Shihab, Membumikan ..., hlm. 424425.

21 Lihat pendapat Moh. Rasyid Ridha tentang masalah ini dalam Tafsir Al-Manar ketika menafsirkan ayat tersebut. sebagainya. Mereka itulah ulul amri.

4. Mengembalikan persoalan yang diperselisihkan kepada kaidah-kaidah umum yang terdapat dalam al-Qur'an dan Sunnah. ${ }^{2222}$

\section{Sistem Pemerintahan Islam Perspektif Historis}

Dalam menyebarkan agama Islam Nabi Muhammad Saw. mengalami dua periode yang dikenal sejarah sebagai periode Makkah dan Madinah. Periode Makkah merupakan masa penanaman aqidah dan akhlak yang berlangsung selama sekitar tiga belas tahun, dan periode Madinah merupakan masa turunnya ayatayat al-Quran yang menjelaskan tentang semua persoalan yang dihadapi oleh umat manusia, seperti shalat, zakat, puasa, haji, dan masalah-masalah mu'amalah, seperti jual-beli, kekeluargaan, kriminalitas dan ketatanegaraan. Periode Madinah di kenal sebagai periode revolusi sosial dan politik yang berlangsung selama sepuluh tahun. ${ }^{2323}$

Setelah tiba di kota Yasrib (Madinah), Nabi Muhammad Saw. diterima dan sekaligus resmi menjadi pemimpin penduduk kota itu. Berbeda dengan periode Makkah, pada periode Madinah Islam merupakan kekuatan politik. Nabi Muhammad mempunyai kedudukan bukan hanya sebagai pemimpin agama, tetapi juga sebagai kepala negara. ${ }^{2424}$ Peristiwa hijrah Nabi pada tahun $622 \mathrm{M}$ merupakan momen penting dalam sejarah perkembangan Islam. Nabi segera menyatukan seluruh potensi kekuatan yang ada, terutama penyatuan golongan Muhajirin dan Anshor. Sejak saat itulah, terutama saat dibentuknya persetujuan bersama yang dikenal dengan "Konstitusi Madinah" (Madinah Constitution), Nabi mulai membentuk

22 M. Quraish Shihab, Membumikan ..., hlm. 428429.

23 Mun'im A. Sirry, Sejarah Fiqh Islam (Sebuah Pengantar), (Surabaya: Risalah Gusti, 1995), hlm. 22-24.

24 Harun Nasution, Islam Ditinjau dari Berbagai Aspeknya, Jilid III, (Jakarta : UI Press, 1985), Cetakan V, hlm, 101. 
tatanan baru dalam Islam, yang disebut Hugh Kennedy sebagai "a new form of social organization". 2525

Di kota Madinah (saat itu masih bernama Yasrib), untuk pertama kalinya lahir satu komunitas Islam yang bebas dan merdeka di bawah pimpinan Nabi dan terdiri atas pengikut Nabi yang datang dari Makkah (Muhajirin) dan penduduk Madinah yang telah memeluk Islam, serta yang telah mengundang Nabi untuk Hijrah ke Madinah (Anshar). Umat Islam saat itu bukanlah satu-satunya komunitas di Madinah. Di antara penduduk Madinah, terdapat juga komunitas-komunitas lain, yaitu orang-orang Yahudi, sisa-sisa suku Arab yang belum mau menerima Islam dan masih tetap memuja berhala. Dengan kata lain, umat Islam di Madinah merupakan bagian dari suatu masyarakat majemuk. ${ }^{2626}$

Tidak lama setelah Nabi menetap di Madinah atau menurut sementara ahli sejarah belum cukup dua tahun dari kedatangan Nabi di kota itu, beliau mempermaklumkan suatu piagam yang mengatur kehidupan dan hubungan antara komunitas-komunitas yang merupakan komponen-komponen masyarakat majemuk di Madinah, yang dikenal sebagai Piagam Madinah. Dari item-item yang tercantum dalam piagam Madinah (keseluruhan terdapat empat puluh tujuh), dapat ditarik kesimpulan bahwa isi Piagam Madinah merupakan batu-batu dasar bagi landasan kehidupan bernegara untuk masyarakat majemuk di Madinah, yakni: (1) semua pemeluk Islam, meskipun berasal dari berbagai suku, tetapi merupakan satu komunitas; (2) hubungan antara sesama anggota komunitas Islam dengan anggota komunitas-komunitas lain didasarkan atas prinsip-prinsip: (a) Bertetangga baik; (b) Saling membantu dalam menghadapi musuh bersama; (c) Membela mereka yang teraniaya; (d) Saling menasehati, dan (e)

25 Hugh Kennedy, The Prophet and the Age of the Caliphates, (London and New York : Longman, 1986), hlm. 34.

26 Munawir Sjadzali, Islam ..., hlm. 10.
Menghormati kebebasan beragama. ${ }^{2727}$

Berkaitan dengan sistem pemerintahan yang di bangun oleh Nabi Muhammad sampai beliau hijrah ke Madinah, Muhammad Husein Haikal menjelaskan bahwa Nabi sendiri rupanya tidak hendak mengubah sedikit pun sistem pemerintahan Arab yang masih berlaku. Nabi menyerahkan sepenuhnya urusan tersebut kepada setiap umat untuk mengaturnya sendiri. Setiap kali ditanya tentang masalah itu, Nabi Muhammad Saw. selalu menjawab: Kalian lebih tahu tentang urusan dunia kalian. ${ }^{2828}$ Pendapat senada dikemukakan oleh Suyuthi Pulungan. Ia menjelaskan bahwa isi Piagam Madinah merupakan ketetapan yang menarik karena di antara ketetapannya tidak ada yang menyebut tentang bentuk pemerintahan, struktur kekuasaan, perangkat-perangkat pemerintahan sebagai lazimnya konstitusi. Hal ini disebabkan muatannya hanya berupa prinsip-prinsip di bidang mu'amalah sebagaimana al-Qur'an dalam hal yang sama hanya menyebut prinsip-prinsipnya saja, dan tidak menetapkan sistem dan bentuk pemerintahan. ${ }^{2929}$

Islam tidak menetapkan sistem khusus mengenai kekhalifahan (kepemimpinan umat sepeninggal Rasulullah Saw). Soal itu diserahkan sepenuhnya kepada ahlu al-halli wa al-'aqdi (orang-orang terkemuka di kalangan umat Islam yang dipandang mempunyai otoritas untuk memecahkan berbagai persoalan yang dihadapi umat). Kaum muslimin di- biarkan untuk menetapkan sendiri rinciannya dalam undang-undang tertulis atau konsensus. Nabi menyerahkan sepenuhnya urusan tersebut kepada setiap umat untuk mengaturnya sendiri. ${ }^{3030}$ Sepeninggal

27 Munawir Sjadzali, Islam ..., hlm. 15-16.

28 Muhammad Husein Haikal, Al-Hukumah al-Islamiyyah, terjemah Tim Pustaka Firdaus, "Pemerintahan Islam," (Jakarta: Pustaka Firdaus, 1993, hlm. 11.

29 J. Suyuthi Pulungan, Prinsip-Prinsip Pemerintahan dalam Piagam Madinah Ditinjau dari Pandangan Al- Qur'an, (Jakarta: Raja Grafindo Persada dan LSIK, cetakan kedua, 1996), hlm. 8.

30 Muhammad Hussein Haikal, Pemerintahan ..., 
Nabi Muhammad Saw. pemerintahan Islam (umat Islam) dipimpin oleh para khalifah yang dikenal dengan sebutan Khulafa' ar-Rasyidin (para pemimpin yang mendapatkan petunjuk). Mereka adalah Abu Bakar as-Siddiq (11-13 H/ 632-634 M), Umar bin Khattab (13-23 H/634-644 M), Usman bin Affan (23-35 H/ 644-656 M), dan Ali bin Abi Thalib (35-40 H/ 656-661 M). ${ }^{3131}$

Cara pemilihan keempat khalifah tersebut berbeda-beda, dan ini merupakan hal yang menarik untuk dikaji lebih lanjut. Abu Bakar terpilih setelah melalui perdebatan sengit antara perwakilan golongan Muhajirin dan Anshar di Saqifah Bani Sa'idah. ${ }^{3232}$ Proses terpilihnya Abu Bakar terjadi secara tiba-tiba dan di luar rencana matang. Hal ini dilakukan karena saat itu kelompok Anshar yang sedang melangsungkan pertemuan di Saqifah sudah sepakat untuk mengangkat Saad bin Ubadah, seorang tokoh Anshar dari suku Khazraj sebagai khalifah pengganti Nabi. Umar yang mendengar berita itu segera mengajak Abu Bakar dan Abu Ubaidah bin Jarah untuk datang ke pertemuan tersebut. Peristiwa terpilihnya Abu Bakar dengan cara-cara seperti itu menimbulkan "permasalahan" di kemudian hari, yang disebut oleh Mahmoud M. Ayoub sebagai "the crisis of succession". ${ }^{3333}$

Umar dipilih untuk menjadi khalifah melalui penunjukan atau "wasiat" Abu bakar ketika ia sakit mendadak pada tahun

hlm. 11. Dalam kaitannya dengan imamah yang diserahkan kepada ahlu al-Halli wa al-Aqdi perlu disimak pandangan al-Mawardi tentang masalah tersebut, dengan menyebut istilah ahl al-ikhtiar dan ahl al-imamah. Lihat al-Mawardi, Al-Ahkam ..., hlm. 6 .

31 Lihat Hugh Kennedy, The Prophet ..., hlm. 5081.

32 Saqifah Bani Sa'idah adalah suatu tempat untuk melangsungkan balai pertemuan Bani Sa'idah di Madinah. Proses pengangkatan Abu Bakar terjadi pada hari kedua wafatnya Nabi dan jenazahnya Nabi belum dimakamkan sehingga hal ini yang menyebabkan keluarga dekat Nabi marah. Lihat Munawir Sjadzali, Islam ..., hlm. 21-24.

33 Mahmoud M. Ayoub, The Crisis of Muslim History, (Oxford: the British Library, 2003), hlm. $7-25$. ketiga menjabat khalifah. Usman terpilih menjadi khalifah melalui perdebatan serius antara anggota "komite" (the syura council) yang beranggotakan enam orang pilihan Umar, yaitu Ali bin Abi Thalib, Usman bin Affan, Abdurrahman bin 'Auf, Sa'ad bin Abi Waqqas, Zubair bin Awwam dan Thalhah bin Ubaidillah. Apabila suara yang ditentukan oleh enam orang tersebut sama, maka diserahkan kepada Abullah bin Umar, dan apabila masih tidak disetujui maka calon yang didukung oleh Abdurrahman bin Auf yang jadi khalifah. ${ }^{3434}$

Ali bin Abi Thalib terpilih menjadi khalifah keempat setelah dua belas tahun dari kekhalifahan Usman. Proses pengangkatannya dilakukan melalui pemilihan yang penyelenggaraannya jauh dari sempurna. Setelah pemberontak membunuh Usman bin Affan, mereka mendesak Ali agar bersedia diangkat menjadi khalifah. Pada waktu itu Madinah dalam kondisi kosong. Banyak sahabat senior yang berkunjung ke wilayahwilayah yang baru ditaklukkan, dan hanya sedikit yang masih tinggal di Madinah, di antaranya Thalhah bin Ubaidillah dan Zubair bin Awwam. Tidak semua yang masih ada itu sepenuhnya mendukung Ali, seperti Sa'ad bin Abi Waqas dan Abdullah bin Umar. Ketika ketiga tokoh senior, yakni Thalhah, Zubair dan Sa'ad berbaiat kepada Ali, orang-orang segera mengikuti untuk berbaiat kepada Ali, baik dari kelompok Muhajirin maupun Anshar. ${ }^{3535}$ Pada zaman kepemimpinan khalifah empat ini sistem atau corak pemerintahan mengambil bentuk aristokrat demokratik, yaitu sistem pemerintahan yang dalam menyelesaikan setiap persoalan yang timbul dengan cara musyawarah yang anggotanya terdiri atas

34 Proses terpilihnya Usman menjadi Khalifah ini berjalan "alot" dan tegang serta sangat melelahkan. Perbedaan pikiran dari keenam anggota "dewan komite/syura" menjadikan suasana semakin panas. Mahmoud Ayoub menyebutkan sebagai krisis kedua (the second crisis) dalam sejarah umat Islam. Lihat Mahmoud M. Ayoub, The Crisis ..., hlm. 39-49. Lihat juga Munawir Sjadzali, Islam ..., hlm. 25-27.

35 Munawir Sjadzali, Islam ..., hlm. 27-28. 
para aristokrat. Bibit perpecahan umat terjadi pada masa Usman bin Affan dan mencapai puncaknya pada masa Ali bin Abi Thalib. ${ }^{3636}$ Sebagian pakar menyebut sistem pemerintahan pada masa ini dengan "autocratic power" (kekuatan autokrasi) dan a dynastic monarchy" (dinasti monarkhi). ${ }^{3737}$

Setelah Khulafa' ar-Rasyidin, kekhalifahan dilanjutkan oleh Bani Umayah dengan Mu'awiyah bin Abi Sufyan sebagai pendirinya. Pada masa ini corak pemerintahan sudah berubah menjadi bentuk kerajaan. Pengangkatan kepala negara tidak lagi berdasarkan musyawarah secara demokratis, melainkan berdasarkan "penunjukan" putra mahkota secara otokratis. Pada masa Abbasiyah corak yang diterapkan sama dengan masa Umayah, yakni sistem kerajaan yang bercorak otokratis. Setelah kekuasaan Abbasiyah hancur di tahun $1258 \mathrm{M}$ karena serbuan bangsa Mongol yang dipimpin oleh Hulagu Khan, kekuasaan Islam mengambil bentuk kesultanan, yaitu kesultanan Usmani, kesultanan Syafawi dan kesultanan Moghul yang menerapkan sistem kerajaan.

\section{Agama dan Negara dalam Konsep Figh Siyasah}

Agama dan negara merupakan dua satuan sejarah yang berbeda hakekatnya. Agama, menurut Kuntowijoyo adalah kabar gembira dan pemberi peringatan (basyiran wa naziran), sedangkan negara adalah kekuatan pemaksa. Agama mempunyai khatib, jiwa dakwah dan ulama, sedangkan negara mempunyai birokrasi, pengadilan, dan tentara. Agama dapat mempengaruhi jalannya sejarah melalui kesadaran bersama (collective conscience), sedangkan negara mempengaruhi sejarah dengan keputusan kekuasaan dan perang. Agama adalah kekuatan dari dalam dan negara adalah kekuatan dari luar. ${ }^{3838}$ Pembahasan

36 Abuddin Nata, Metodologi Studi Islam, (Jakarta : Raja Grafindo Persada, 2000), hlm. 270-271.

37 Mahmoud M. Ayoub, The Crisis ..., hlm. 42.

38 Kuntowijoyo, Identitas Politik Umat Islam, (Bandung: Mizan dan Ummat, cetakan I, 1997), hlm 191-192. mengenai agama (din) dan negara (daulah) merupakan hal yang selalu menarik untuk dilakukan. Hal ini dikarenakan masalah tersebut menjadi salah satu subyek penting dalam kajian siyasah (politik), yang meskipun telah diperdebatkan para pemikir Islam sejak hampir seabad lalu hingga dewasa ini, tetapi masih belum terpecahkan dengan tuntas. ${ }^{3939}$

Diskusi tentang hal ini bahkan belakangan semakin hangat tatkala antusiasme "kebangkitan Islam" melanda hampir seluruh dunia Islam. Pengalaman masyarakat Muslim di berbagai penjuru dunia, khususnya sejak usai Perang Dunia II mengesankan terdapatnya hubungan yang canggung antara Islam (din) dan negara (daulah), atau bahkan politik pada umumnya. Berbagai "eksperimen" dilakukan untuk menyelaraskan antara din dengan konsep dan kultur masyarakat Muslim, dan eksperimen-eksperimen itu dalam banyak hal sangat beragam. ${ }^{4040}$

Dalam pemikiran politik Islam, terdapat paling tidak tiga paradigma tentang hubungan agama dan negara. Nuansa di antara ketiga paradigma ini terletak pada konseptualisasi yang diberikan kepada kedua istilah tersebut. ${ }^{4141}$ Perbedaan konseptual tersebut disebabkan oleh pasangan-pasangan istilah, seperti duniaakhirat, umur ad-dunya-umur ad-din (urusan dunia dan agama), din-daulah, (agama dan negara) yang diperkenalkan oleh sumbersumber Islam sehingga mengesankan adanya dikotomi. Paradigma pertama memperkenalkan konsep bersatunya agama dannegara.Agama(Islam) dan negara dalam hal ini, tidak dapat dipisahkan (integrated). Menurut paradigma ini negara merupakan lembaga politik dan keagamaan sekaligus. Pemerintahan negara diselenggarakan atas dasar "kedaulatan Ilahi" (divine sovereignity), karena memang kedaulatan itu

39 Azyumardi Azra, Pergolakan Politik Umat, (Jakarta: Paramadina, 1996), hlm 1.

40 Azyumardi Azra, Pergolakan ..., hlm. 1.

41 M. Dien Syamsuddin, Etika dalam Membangun Masyarakat Madani, (Jakarta: Logos, 2002), hlm. 57. 
berasal dan berada di "Tangan" Tuhan. ${ }^{4242}$ Paradigma seperti ini banyak dianut oleh kelompok Syi'ah. Paradigma pemikiran Syi'ah memandang bahwa negara (Imamiah) adalah lembaga keagamaan dan mempunyai fungsi keagamaan. Menurut pandangan Syi'ah, berhubung legitimasi keagamaan berasal dari Tuhan dan diturunkan lewat garis keturunan Nabi Muhammad Saw., maka legitimasi politik harus berdasarkan legitimasi keagamaan dan hal ini hanya dimiliki oleh keturunan Nabi. ${ }^{4343}$

Negara, dalam perspektif Syi'ah, lebih cenderung bersifat teokratis karena ia merupakan lembaga politik yang didasarkan atas legitimasi keagamaan dan mempunyai fungsi menyelenggarakan kedaulatan Tuhan. Negara teokrasi mengandung pengertian bahwa kekuasaan mutlak berada di tangan Tuhan dan konstitusi negara berdasarkan pada wahyu Tuhan (syariah). Sifat teokratis negara dalam pandangan Syi'ah dapat ditemukan dalam pemikiran-pemikiran ulama Syi'ah. Imam Khomeini umpamanya, menyatakan bahwa dalam negara Islam wewenang menetapkan hukum berada pada Tuhan. Tiada seorang pun berhak menetapkan hukum. Hukum yang boleh berlaku hanyalah hukum Tuhan. ${ }^{444}$ Paradigma pemikiran ini juga dianut oleh kelompok yang sering dikategorikan sebagai "Fundamentalisme Islam" yang menganggap bahwa Islam adalah agama yang sempurna dan lengkap sebagai pengaturan bagi segala aspek kehidupan manusia, termasuk kehidupan bernegara. Menurut salah seorang tokoh kelompok ini, al-Maududi (w. 1979 M), syari'ah tidak mengenal pemisahan antara agama dan politik atau antara agama dan negara. Syari'ah adalah skema kehidupan yang sempurna dan meliputi seluruh tatanan kemasyarakatan, tidak ada yang

42 M. Dien Syamsuddin, Etika ..., hlm. 58.

43 M. Dien Syamsuddin, Etika ..., hlm. 58.

44 Karya Imam Khomeini yang banyak menjelaskan tentang "Negara Islam" adalah buku al-Hukumah al-Islamiyah, (Teheran: Muktabah al-Islamiyah al-Kubra, t. th.). lebih dan tidak ada yang kurang. ${ }^{4545}$

Dasar keyakinan atau anggapan yang melandasi pikiran-pikiran Maududi tentang kenegaraan menurut Islam adalah: pertama, Islam adalah suatu agama yang paripurna, lengkap dengan petunjuk untuk mengatur semua segi kehidupan manusia, termasuk kehidupan politik dengan arti di dalam Islam terdapat pula sistem politik. Kedua, kekuasaan tertinggi yang dalam istilah politik disebut kedaulatan berada di "Tangan Allah" dan umat manusia hanyalah pelaksana dan kedaulatan Allah tersebut sebagai khalifah-khalifah Allah di muka Bumi. Ketiga, sistem politik Islam adalah batasbatas dan ikatan-ikatan geografi bahasa dan kebangsaan. ${ }^{4646}$

Paradigma kedua memandang antara agama dan negara tidak berhubungan sama sekali (terpisah). Menurut aliran ini Nabi Muhammad hanyalah seorang Rasul biasa seperti halnya rasul-rasul sebelumnya, dengan tugas tunggal mengajak manusia kembali kepada kehidupan yang mulia dengan menjunjung tinggi budi pekerti luhur, dan Nabi tidak pernah dimaksudkan untuk mendirikan dan menggali satu negara. ${ }^{4747}$ Dalam konteks Islam, paradigma ini dikenal dengan paradigma sekularistik yang menolak pendasaran negara kepada Islam, atau paling tidak menolak determinasi Islam, akan bentuk tertentu dari negara. ${ }^{4848}$ Salah seorang pemrakarsa paradigma ini adalah Ali Abdul al-Raziq (1888-1966 M). Ar-Raziq lahir pada tahun $1888 \mathrm{M}$ dan wafat tahun 1966 M. Ia merupakan penganut Mohammad Abduh, meskipun mungkin tidak sempat belajar darinya karena ketika Abduh wafat pada tahun 1905, Ar-Raziq baru berusia kira-kira tujuh belas tahun. Ali Abdul al-Raziq merupakan tokoh yang paling kontroversial, dan karenanya paling terkenal terutama karena buku yang

45 Lihat Abul A'la Maududi, "Political Theory of Islam” dalam Kurshid Ahmad (Ed), Islamic Law and Constitution, (Lahore: Lahore Press, 1967), hlm. 243.

46 Munawir Sjadzali, Islam ..., hlm. 66.

47 Munawir Sjadzali, Islam ..., hlm. 1.

48 M. Dien Syamsuddin, Etika ..., hlm. 62. 
ditulisnya pada tahun 1925 dengan judul alIslam wa Usul al-Hukm (Islam dan prinsipprinsip pemerintahan).

Dalam bagian pertama buku tersebut, Ali Abdur Raziq menguraikan tentang definisi Khalifah beserta ciri-ciri khususnya, kemudian dipertanyakan tentang dasar anggapan bahwa mendirikan pemerintahan dengan pola khilafah itu merupakan keharusan (agama), dan akhirnya dikemukakan bahwa baik dari segi agama maupun rasio, pada pemerintahan khalifah itu tidak perlu. ${ }^{4949}$ Berkaitan dengan masalah tersebut, Ali Abdul al-Raziq mengemukakan:

"Agama Islam terbebas dari khilafah yang dikenal oleh kaum Muslim selama ini dan juga terbatas dari apa yang mereka bangun dalam bentuk kejayaan dan kekuatan khilafah bukanlah bagian dari rencana atau takdir agama tentang urusan kenegaraan, tetapi ia semata-mata hanyalah rancangan politik murni yang tidak ada urusan sama sekali dengan agama. Agama tidak pernah mengenalnya, menolaknya, memerintahkannya, atau pun melarangnya. Ia adalah sesuatu yang ditinggalkan kepada kita agar kita menentukannya berdasarkan kaidah rasional pengalaman dan aturanaturan politik". ${ }^{5050}$

Dalam bagian kedua, ar-Raziq menguraikan tentang pemerintahan dan Islam tentang perbedaan antara risalah atau misi kenabian dengan pemerintahan, dan pada akhirnya kesimpulannya adalah bahwa risalah kenabian itu bukan pemerintahan dan agama itu bukan negara. Bagian ketiga diuraikan tentang khalifah atau lembaga khalifah dan pemerintahan dalam lembaran sejarah. Dalam hal ini arRaziq berusaha membedakan antara mana yang Islam dan mana yang Arab, mana yang khalifah Islamiyah dan mana yang negara Arab, serta mana yang agama dan

49 Dikutip dari Munawir Sjadzali, Islam ..., hlm. 139-140.

50 Lihat Ali 'Abd al-Raziq, Al-Islam wa Usul al Hukm, Cetakan I, (Kairo: Dar al Misr, 1925), hlm. 403. mana yang politik. ${ }^{5151}$ Argumen utama Raziq adalah bahwa kekhalifahan tidak mempunyai dasar dalam al-Qur'an dan alHadis. Kedua sumber utama Islam ini tidak menyebut istilah khilafah dalam pergantian kekhalifahan yang pernah ada dalam sejarah. Lebih dari itu, tidak ada petunjuk yang jelas dalam al-Qur'an dan al-Hadis yang menentukan suatu bentuk sistem politik mana yang didirikan oleh umat Islam. ${ }^{5252}$

Paradigma ketiga, hubungan agama dan negara memandang bahwa agama dan negara berhubungan secara timbal balik dan saling memerlukan. Dalam hal ini agama memerlukan negara, karena dengan negara agama dapat berkembang. Sebaliknya negara memerlukan agama, karena dengan agama, negara dapat berkembang dalam bimbingan etika dan moral. ${ }^{5353}$ Salah satu tokoh yang mengembangkan paradigma pemikiran ini adalah Abu Hasan Ali alMawardi (w. 1058 M). Nama lengkapnya adalah Abu Hasan Ali b. Habib al-Mawardi al-Bashri, yang hidup antara tahun 346H/975 $\mathrm{M}$ dan $450 \mathrm{H} / 1059 \mathrm{M}$. Ia merupakan seorang pemikir Islam terkenal, tokoh terkemuka mazhab Syafi'i, dan pejabat tinggi yang besar pengaruhnya dalam pemerintahan Abbasiyah. Setelah berpindah-pindah dari satu kota ke kota lain sebagai hakim, akhirnya ia kembali dan menetap di Bagdad, dan mendapat kedudukan yang terhormat pada pemerintahan Khalifah Qadir. ${ }^{5454}$

Dalam karya monumentalnya, Kitab al-Ahkam al-Sultaniyah, al- Mawardi mengemukakan pada bagian awal bahwa imamah (kepemimpinan) merupakan instrumen untuk meneruskan misi kenabian guna memelihara agama (harasah al-din) dan pengatur dunia (siyasah ad-dunya). 5555 Pemeliharaan agama dan pengaturan dunia merupakan dua jenis aktifitas yang

51 Munawir Sjadzali, Islam ..., hlm. 140.

52 Lihat Ali 'Abd al- Raziq, Al-Islam ..., hlm. 42.

53 M. Dien Syamsuddin, Etika ..., hlm.60.

54 Munawir Sjadzali, Islam ..., hlm, 58.

55 Ali al-Hasan Ali b. Muhammad b. Habib AlBashri, al-Bagdadi al- Mawardi, Al-Ahkam al-Sultaniyah wa al-Wilayah ad-Diniyah, (Beirut: Dar al- Fikr, Cet. I, 1380 H/ 1960 M), hlm. 5. 
berbeda, namun berhubungan secara simbiotik. Al-Mawardi menjelaskan bahwa imamah merupakan hal yang wajib dalam umat Islam berdasarkan Ijma'. Alasan yang menjadikan wajibnya imamah tersebut, menurut Mawardi terdapat dua pendapat di kalangan umat Islam, yakni sebagian mengemukakan wajib dengan akal (rasio). Akal memandang kewajiban imamah ini untuk keselamatan manusia dari tindakan zalim, pertikaian (tanazu'), dan permusuhan (takhasum). Segolongan yang lain berpendapat bahwa kewajiban imamah dengan alasan Syar'i karena seorang imam bertugas untuk menegakkan urusan-urusan syari'ah (umur as- Syari'ah). ${ }^{5656}$

Menurut Mawardi, untuk seleksi atau pemilihan imam diperlukan dua hal. Pertama, Ahl al-Ikhtiar atau mereka yang berwenang untuk memilih imam bagi umat. Mereka harus memenuhi tiga syarat, yaitu: (1) Memiliki sifat adil, (2) Memiliki ilmu pengetahuan yang memungkinkan mereka mengetahui siapa yang memenuhi syarat untuk diangkat sebagai imam, (3) Memiliki wawasan yang luas (arra'y) dengan kearifan (al-hikmah) yang memungkinkan mereka memilih siapa yang paling tepat untuk menjadi imam, dan paling mampu mengelola kepentingan umat di antara mereka yang memenuhi syarat untuk jabatan itu. ${ }^{5757}$ Kedua, Ahl al-Imamah (kualifikasi pemimpin), yaitu: (1) sikap adil ('adalah) dengan segala persyaratannya; (2) ilmu pengetahuan yang memadai untuk ber-ijtihad, (3) sehat pendengaran, penglihatan dan lesannya; (4) anggota-anggota tubuhnya utuh (salamah al-a'da'i); (5) wawasan yang memadai untuk mengatur kehidupan rakyat (siyasah ar-ra'iyyah) dan mengelola kepentingan umum (tadbir al-masalih); (6) keberanian, (assyaja'ah) yang memadai untuk melindungi rakyat; dan (7) keturunan Quraisy. ${ }^{5858}$

Syari'ah (agama), menurut al-Mawardi mempunyai posisi sentral dalam negara,

56 Al-Mawardi, Al-Ahkam ..., hlm. 5.

57 Al-Mawardi, Al-Ahkam ..., hlm. 6.

58 Al-Mawardi, Al-Ahkam ..., hlm. 6. terutama sebagai sumber legitimasi terhadap realitas politik. Dalam penilaian Dien Syamsuddin, al-Mawardi mencoba mengkompromikan antara realitas dan idealitas politik seperti disyaratkan oleh agama, dan menjadikan agama sebagai alat justifikasi kepatutan politik. Dengan demikian, al-Mawardi sebenarnya mengenalkan pendekatan pragmatik dalam menyelesaikan persoalan politik ketika dihadapkan dengan prinsip-prinsip agama. ${ }^{5959}$

Pemikir lain yang mendukung paradigma pemikiran ketiga ini adalah Imam al-Ghazali $(450 \mathrm{H} / 1058 \mathrm{M}-505$ H/1111 M). Meskipun al-Ghazali tidak secara khusus dikenal sebagai pemikir politik, namun beberapa karyanya mengandung pemikiran-pemikiran politik yang signifikan, seperti Ihya' Ulum ad-Din, khususnya kitab al-sya'ab, al-Iqtisad fi alI'tiqad (moderasi dalam kepercayaan) dan at-Tibr al-Masbuk fi Nasihah al-Muluk (batang logam mulia tentang nasihat untuk rajaraja). ${ }^{6060}$ Menurut al-Ghazali, kewajiban seorang kepala atau pemimpin negara tidak berdasarkan rasio, tetapi berdasarkan keharusan agama. Hal ini disebabkan persiapan untuk kesejahteraan ukhrawi harus dilakukan melalui pengamalan dengan penghayatan akar agama secara betul. Suasana tersebut baru mungkin apabila dunia tertib, aman, dan tenteram, dan untuk menciptakan dunia yang demikian diperlukan pemimpin atau kepala negara yang ditaati, atau dengan kata lain, tidak mungkin mengamalkan ajaran agama secara baik dalam kondisi dan situasi dunia yang tidak mendukung. Agama dan raja menurut al-Ghazali ibarat dua anak kembar, agama adalah suatu pondasi dengan sultan penjaganya. Sesuatu tanpa pondasi akan mudah runtuh, dan suatu pondasi tanpa penjaga akan hilang. ${ }^{6161}$

59 M. Dien Syamsuddin, Etika ..., hlm. 61.

60 Munawir Sjadzali, Islam ..., hlm. 74.

61 Munawir Sjadzali, Islam ..., hlm. 76. 


\section{KESIMPULAN}

Berdasarkan uraian di atas dapat disimpulkan beberapa temuan sebagai berikut:

1. Sistem pemerintahan dalam perspektif Islam tidak disebutkan secara jelas dalam al-Quran dan Sunnah sehingga para pemikir politik Islam berbeda pendapat tentang sistem pemerintahan apa yang harus diterapkan ke dalam sebuah negara-bangsa (nation-state).

2. Dalam perspektif historis, sistem pemerintahan pada masa Nabi Muhammad lebih mementingkan substansi nilai-nilai Islam ke dalam sistem pemerintahan negara. Hal ini dapat dilihat pada aturan-aturan yang tertuang dalam Piagam Madinah, sedangkan pemerintahan pada masa Khulafa' ar-Rasyidin menggunakan sistem "autocratic power" (kekuatan autokrasi) dan a dynastic monarchy" (dinasti monarkhi).

3. Para pemikir politik Islam berbeda pandangan dalam menyikapi relasi agama dan negara dalam konsep figh siyasah. Perbedaan ini terbagi menjadi tiga kelompok, yaitu pertama, agama dan negara harus terintegrasi dan tidak dapat dipisahkan sebab negara merupakan lembaga politik dan sekaligus keagamaan, kedua, antara agama dan negara tidak berhubungan sama sekali (terpisah) karena Nabi Muhammad hanyalah seorang Rasul biasa seperti halnya rasul-rasul sebelumnya, dengan tugas tunggal mengajak manusia kembali kepada kehidupan yang mulia, ketiga, agama dan negara berhubungan secara timbal balik dan saling membutuhkan. Wallahu A Iam.

\section{DAFTAR PUSTAKA}

Ayoub, Mahmoud, 2003, The Crisis of Muslim History, Oxford: the British Library.

Azra, Azyumardi, 1996, Pergolakan Politik Islam, Jakarta : Paramadina.

Haikal, Muhammad Husein, 1993, Al-Hukumah al-Islamiyah, penerjemah Tim Pustaka Firdaus, "Pemerintahan Islam," Jakarta: Pustaka Firdaus.

Kennedy, Hugh, 1986, The Prophet and the Age of the Caliphates, London and New York: Longman.

Khomeini, Imam, t.t., Al-Hukumah al-Islamiyah, Teheran: Muktabah al-Islamiyah al-Kubra. Kuntowijoyo, 1997, Identitas Politik Umat Islam, Bandung: Mizan dan Ummat, cetakan I.

Maududi, Abu al-A'la, 1967, "Political Theory of Islam" dalam Kurshid Ahmad (Ed), Islamic Law and Constitution, Lahore.

Mawardi, Ali al-Hasan Ali b. Muhammad b. Habib Al- Bashri, al-Bagdadi, 1960, Al-Ahkam as-Sultaniyah wa al-Wilayah ad-Diniyah, Beirut: Dar al- Fikr, Cetakan I.

Nasution, Harun, 1985, Islam Ditinjau dari Berbagai Aspeknya, Jilid III, Jakarta : UI Press.

Nata, Abdudin, 2000, Metodologi Studi Islam, Jakarta : Raja Grafindo Persada.

Pulungan, J. Suyuti, 1996, Prinsip-Prinsip Pemerintahan dalam Piagam Madinah Ditinjau dari Pandangan Al-Qur'an, Jakarta: Raja Grafindo Persada dan LSIK, Cetakan Kedua.

Raziq, Ali 'Abd al-, 1925, Al-Islam wa Usul al- Hukum, Cetakan I, Kairo: Dar al- Misr.

Ridha, Moh. Rasyid, t.t., Tafsir Al-Manar, Beirut : Dar al-Fikr.

Sjadzali, Munawir, 1993, Islam dan Tata Negara, Jakarta : UI Press, Edisi Kelima.

Shihab, M. Quraish, 1992, Membumikan Al-Qur'an, Bandung : Mizan.

Bandung : Mizan, Cetakan XI.

Shobron, Sudarno, dkk., 2014, Pedoman Penulisan Tesis, (Surakarta: Sekolah Pascasarjana UMS).

Sirry, Mun'im A., 1995, Sejarah Figh Islam (Sebuah Pengantar), Surabaya: Risalah Gusti. 
PROFETIKA, Jurnal Studi Islam, Vol. 19, No. 2, Desember 2018: 94-107

Suryabrata, Sumadi, Metode Penelitian, 1998, (Jakarta: Rajawali Press).

Syamsuddin, M. Dien, 2002, Etika dalam Membangun Masyarakat Madani, Jakarta: Logos. 